\title{
Oleins as a source of estolides for biolubricant applications
}

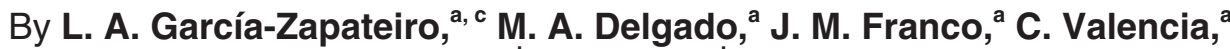 \\ M. V. Ruiz-Méndez, ${ }^{b}$ R. Garcés, ${ }^{b}$ and C. Gallegos ${ }^{*}$
}

\author{
a Departamento de Ingeniería Química. Facultad de Ciencias Experimentales. \\ Campus de "El Carmen". Universidad de Huelva. 21071 Huelva. Spain. \\ ${ }^{b}$ Instituto de la Grasa (CSIC). Avda. P. García Tejero, 4-41012 Sevilla. Spain \\ ${ }^{c}$ Grupo de Investigación de Proyectos Alimentarios (PROAL). Facultad de Ingeniería. \\ Universidad de Cartagena de Indias (Colombia) \\ ( ${ }^{\star}$ Corresponding author: cgallego@uhu.es)
}

\section{RESUMEN}

Oleinas como materias primas de estólidos para aplicaciones como biolubricantes.

En este estudio se presenta la síntesis de estólidos a partir de oleinas de girasol alto-oleico y su utilización potencial como modificadores de la viscosidad en aplicaciones como biolubricantes. La reacción de síntesis se controló durante $24 \mathrm{~h}$. El peso molecular de los estólidos se incrementa durante todo el periodo de reacción. Las viscosidades dinámicas y densidades de los diferentes estólidos se midieron en un rango de temperatura entre 10 y $120^{\circ} \mathrm{C}$. El máximo de viscosidad y de peso molecular se alcanza al cabo de 12 horas de reacción, sin embargo, el incremento mayor de viscosidad se produce durante las 3 primeras horas de tratamiento debido al importante aumento del peso molecular del estólido.

PALABRAS CLAVE: Aceite de girasol alto-oleico - Biolubricante - Estólidos - Oleinas - Subproductos.

\section{SUMMARY}

Oleins as a source of estolides for biolubricant applications

This study deals with the synthesis of estolides from high-oleic sunflower oil oleins, and its potential use as viscosity modifiers for biolubricant applications. Synthesis reactions were monitored for $24 \mathrm{~h}$. Estolide molecular weight increased continuously with reaction time. Dynamic viscosities and densities of the different estolides were measured in a temperature range comprised between 10 and $120{ }^{\circ} \mathrm{C}$. Maximum viscosities and estolide molecular weight were obtained after $12 \mathrm{~h}$ of reaction. However, the largest viscosity increments were observed within the first 3 hours of processing, due to a dramatic increase in the molecular weight of the estolides.

KEY-WORDS: Biolubricants - By-products - Estolides High-oleic sunflower oil - Oleins.

\section{INTRODUCTION}

Interest in biolubricants derived from renewable sources, like vegetable oils, is growing due to their biodegradability, low toxicity and environmentally benign nature. In this sense, the synthesis of a new class of bio-based esters derived from vegetable oils that exhibit excellent flow properties at low temperatures and oxidative stability has been reported (Kodali, 2002). These advances are also possible due to progress in both vegetable oil biotechnology and chemical modifications, which can be used to apply these natural esters as components of high performance biolubricants. Thus, lubricants may contain a significant number of additives, which are used to either enhance an already existing useful property or impart desirable new characteristics. This is especially important in the case of vegetable oils (Maleque et al., 2003), which usually show some technical disadvantages, such as low thermo-oxidative stability, poor lowtemperature properties, and a limited range of viscosity.

Soapstock and deodorizer distillates are the major by-products from vegetable oil refining. They have little commercial value and are sold at a fraction of the oil cost (Dumont and Narine, 2007). The use of fatty acids from soapstock as a thickener for multigrade lubricating grease has been investigated by El-Adly (2000) and Al-Wakeel and El-Adly (2005). Fatty acids are the major component of soapstock, after water has been extracted. They represent approximately $10 \%$ of the soapstock composition on a wet basis. As fatty acids are mainly used in animal feed, the extraction process must be cheap in order to be justified. Soapstock splitting using a mineral acid is the most common process and the oily phase is sold as olein.

Estolides are a class of ester resulting from the reaction between a carboxylic group in a fatty acid molecule and an unsaturation in another fatty acid molecule to form an ester linkage (Isbell et al., 1994, Isbell et al., 2000, Cermak et al, 2001). The number of these linkages determines the structure and properties of estolides. Different molecular parameters (e.g., molecular weight, branching, etc...) and physical properties (e.g. viscosity and density) are obtained by modifying the nature of the base material and reaction conditions. Moreover, 
these products can improve thermal oxidative stability (Becker et al., 1996, Cermak et al., 2003), and low temperature properties of vegetable oils (Isbell et al., 1994).

Previous results have shown that oleic acid can be used to obtain estolides with remarkable viscosities, a fact that make them promising compounds for biolubricant applications (García-Zapateiro et al., 2008).

On the other hand, the use of olein as a base material for the synthesis of estolides may have additional benefits, mainly from an environmental point of view. This work deals with the synthesis and characterization of estolides derived from high-oleic sunflower oil oleins. These chemical products could be used as additives to increase the viscosity of vegetable oils for lubricant applications. Specifically, the effect of reaction time on estolide viscosities was analyzed.

\section{MATERIALS AND METHODS}

\subsection{Materials}

Oleins resulting from the refining treatment of high-oleic sunflower oil, supplied by COREYSA (Sevilla, Spain), were used as base material to obtain the estolides. Olein composition is shown in Table 1. The quantification of acidity, unsaponifiable matter and fatty acid composition was performed according to the IUPAC Standard Methods.

Highly concentrated sulphuric acid (98\%), monobasic and dibasic phosphates, tetrahydrofuran (THF) and sodium sulphate, from Panreac (Spain), were also used to synthesize the estolides.

\subsection{Synthesis of estolides}

Estolides were obtained from olein by following the sulphuric acid-catalyzed method described elsewhere (Isbell et al., 1994). Fatty acid (100 g) was equilibrated at $50{ }^{\circ} \mathrm{C}$ for $10 \mathrm{~min}$, followed

Table 1

High oleic sunflower oil split soapstock characterization

\begin{tabular}{cr}
\hline Acidity (\% as oleic acid) & 70.83 \\
\hline Unsaponifiable Matter (\%) & 4.09 \\
\hline Glyceridic Fraction (\%) & 25.08 \\
\hline \multicolumn{2}{c}{ Fatty Acid Composition (\%) } \\
\hline $16: 0$ & 5.31 \\
$18: 0$ & 3.36 \\
$18: 1$ & 81.50 \\
$18: 2$ & 6.85 \\
$20: 0$ & 0.64 \\
$20: 1$ & 0.29 \\
$22: 0$ & 1.03 \\
24.0 & 0.49 \\
Others & 0.53 \\
\hline
\end{tabular}

by the addition of concentrated sulphuric acid (in stoichiometric proportion) in a stirred vessel. After 3-24 $\mathrm{h}$, the reaction was quenched by pouring the blend into a separating funnel with $200 \mathrm{~mL}$ hexane. The hexane layer was washed twice with $100 \mathrm{~mL}$ portions of a $1 \mathrm{M} \mathrm{Na}_{2} \mathrm{HPO}_{4}$ aqueous solution. The second wash with phosphate turned the black solution to yellow and formed an emulsion that was broken with THF $(100 \mathrm{~mL})$. The estolide solution was then washed twice with 100 $\mathrm{mL}$ of an aqueous phosphate buffer $(\mathrm{pH}=3.7$, $129.7 \mathrm{~g}$ monobasic phosphate and $0.85 \mathrm{~g}$ dibasic phosphate in $1 \mathrm{~L} \mathrm{H}_{2} \mathrm{O}$ ), dried over $\mathrm{Na}_{2} \mathrm{SO}_{4}$, filtered and concentrated using vacuum distillation (120 to $160{ }^{\circ} \mathrm{C}$; 0.5 torr) to yield $60.04 \mathrm{~g}$ of a dark colored product.

\subsection{Viscosity measurements}

Viscous flow tests were carried out in a rotational controlled-strain ARES rheometer (Rheometrics Scientific, UK), at temperatures between 10 and $120{ }^{\circ} \mathrm{C}$, using a coaxial cylinder geometry (inner diameter: $32 \mathrm{~mm}$, outer diameter: $34 \mathrm{~mm}$, cylinder length: $33.35 \mathrm{~mm}$ ). The shear rate range studied was between 5 and $1000 \mathrm{~s}^{-1}$. All the samples show Newtonian behavior.

\subsection{Density measurements}

Density measurements were performed in a capillary densimeter, model DMA-5000 (Anton Paar, Austria) at temperatures between 10 and $120^{\circ} \mathrm{C}$.

\subsection{Gel permeation chromatography (GPC)}

GPC determinations were performed with a Waters apparatus, equipped with styragel HR 4E

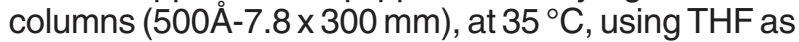
eluent. A Waters 2414 refractive index detector was used. The flow rate was $1.0 \mathrm{~mL} / \mathrm{min}$. The numberaverage molecular weight $\left(M_{n}\right)$, the weight-average molecular weight $\left(M_{w}\right)$, and polydispersity index $\left(M_{w} /\right.$ $M_{n}$ ) were calculated relative to polystyrene standards.

\section{RESULTS AND DISCUSSION}

Table 1 shows the main groups of chemical components of the olein sample used in these assays. As can be observed, the free fatty acid (FFA) content is above $70 \%$, and the glyceridic fraction, which comprises triglycerides and partial glycerides, is $25 \%$. These considerations, and the previous experience with oleic acid (García-Zapateiro et al., 2008), make this byproduct a potentially excellent raw material for the oleochemical industry. Little information about direct applications has been found. In particular, modifications of epoxide resin through synthesis of chlorinated fatty acid and glycidyl ester of fatty acid were proposed from sunflower oil olein (Yazicigil and Ahmetli, 2008). 
Table 2

Densities $(\rho)$, dynamic $(\eta)$ and kinematic viscosities $(v)$ for olein used as base material to obtain estolides, in a temperature range between 10 and $120{ }^{\circ} \mathrm{C}$

\begin{tabular}{cccc}
\hline $\mathbf{T ~}\left({ }^{\circ} \mathbf{C}\right)$ & $\begin{array}{c}\rho \\
\left(\mathbf{g} / \mathbf{c m}^{3}\right)\end{array}$ & $\begin{array}{c}\eta \\
(\mathbf{m P a} \cdot \mathbf{s})\end{array}$ & $v(\mathbf{c S t})$ \\
\hline 10 & 0.9241 & 277.0 & 299.7 \\
25 & 0.9137 & 62.8 & 68.7 \\
40 & 0.9027 & 30.6 & 33.9 \\
70 & 0.8810 & 11.9 & 13.5 \\
100 & 0.8599 & 6.4 & 7.4 \\
120 & 0.8458 & 3.2 & 3.8 \\
\hline
\end{tabular}

Concerning the physical properties of the olein used, Table 2 shows densities, dynamic and kinematic viscosities for this base material, in a temperature range of $10-120{ }^{\circ} \mathrm{C}$. In addition, the viscosity index (VI) is usually calculated to evaluate the thermal susceptibility of lubricating oils. VI was estimated from the kinematic viscosity values at $40^{\circ}$ and $100{ }^{\circ} \mathrm{C}$, according to the ASTM D2270 standard. Olein used in this work had a VI value of 193.

Estolide synthesis from olein starts with an acidcatalyzed conversion of oleic acid into oligomers (Isbell et al., 1994). In fact, a certain degree of polymerization has been detected in the initial olein sample, which shows two peaks in the GPC chromatogram, one corresponding to the mixture of triglycerides and free fatty acid content (around $500 \mathrm{~g} / \mathrm{mol}$, as expected) and another one corresponding to a fraction of higher molecular weight $(1270 \mathrm{~g} / \mathrm{mol})$ (Table 3). This polymerized fraction results from the previous acid and thermal treatments applied on the olein. Aiming to establish the optimum reaction time for estolide synthesis, different reaction times were monitored, i.e., 3, 6, 12 or $24 \mathrm{~h}$, much longer than those usually associated with an esterification process. For all estolide samples, the peak corresponding to the nonpolymerized fraction still appears, but, as can be seen in Table 3, both weight- $\left(\mathrm{M}_{\mathrm{w}}\right)$ and number-average $\left(M_{n}\right)$ molecular weights, related to the polymerized fraction, depend on reaction time. Thus, a dramatic increase in molecular weight was observed after $3 \mathrm{~h}$. Further increments were noticed after $6 \mathrm{~h}$ of reaction. On the contrary, quite similar molecular weights were obtained for reaction times between 6-12 $\mathrm{h}$. Finally, a slight decrease in $M_{w}$ and $M_{n}$ was observed after $24 h$ of reaction, probably due to a thermal degradation of the sample.

Estolides dynamic and kinematic viscosities, at different reaction times and in a temperature range

Table 3

Weight- (Mw) and average molecular weights $\left(M_{n}\right)$ and polydispersity index $\left(M_{w} / M_{n}\right)$ for olein (base material) and estolides, after different reaction times

\begin{tabular}{|c|c|c|c|c|c|c|}
\hline \multirow[b]{2}{*}{ Samples } & \multicolumn{2}{|c|}{$M_{w}(g / m o l)$} & \multicolumn{2}{|c|}{$M_{n}(\mathrm{~g} / \mathrm{mol})$} & \multicolumn{2}{|c|}{$M_{w} / M_{n}$} \\
\hline & Peak 1 & Peak 2 & Peak 1 & Peak 2 & Peak 1 & Peak 2 \\
\hline Olein & 1270 & 510 & 1230 & 510 & 1.03 & 1.00 \\
\hline Estolides - $3 \mathrm{~h}$ & 3900 & 509 & 3100 & 508 & 1.25 & 1.00 \\
\hline Estolides - $6 \mathrm{~h}$ & 4300 & 515 & 3310 & 514 & 1.29 & 1.00 \\
\hline Estolides - $12 \mathrm{~h}$ & 4300 & 507 & 3370 & 506 & 1.27 & 1.00 \\
\hline Estolides - $24 \mathrm{~h}$ & 3900 & 502 & 2910 & 502 & 1.34 & 1.00 \\
\hline
\end{tabular}

Table 4

Densities $(\rho)$, dynamic $(\eta)$ and kinematic viscosities $(v)$ for estolides synthesized from olein after different reaction times, at different temperatures $\left(10-120^{\circ} \mathrm{C}\right)$

\begin{tabular}{|c|c|c|c|c|c|c|c|}
\hline \multicolumn{4}{|c|}{ Reaction time: $3 \mathrm{~h}$} & \multicolumn{4}{|c|}{ Reaction time: $6 \mathrm{~h}$} \\
\hline $\mathrm{T}\left({ }^{\circ} \mathrm{C}\right)$ & $\rho\left(\mathbf{g} / \mathbf{c m}^{3}\right)$ & $\eta(\mathrm{mPa} \cdot \mathbf{s})$ & $v(\mathbf{c S t})$ & $\mathrm{T}\left({ }^{\circ} \mathrm{C}\right)$ & $\rho\left(\mathbf{g} / \mathbf{c m}^{3}\right)$ & $\eta(\mathrm{mPa} \cdot \mathbf{s})$ & $v(\mathbf{c S t})$ \\
\hline 10 & 0.9605 & 5932 & 6176 & 10 & 0.9656 & 6675 & 6912 \\
\hline 25 & 0.9530 & 1007 & 1056 & 25 & 0.9527 & 1337 & 1404 \\
\hline 40 & 0.9397 & 336.1 & 357.6 & 40 & 0.9416 & 400.5 & 425.4 \\
\hline 70 & 0.9200 & 100.9 & 109.6 & 70 & 0.9218 & 96.5 & 104.7 \\
\hline 100 & 0.9005 & 40.2 & 44.7 & 100 & 0.9024 & 38.5 & 42.6 \\
\hline 120 & 0.8875 & 23.7 & 26.7 & 120 & 0.8894 & 23.8 & 26.7 \\
\hline \multicolumn{4}{|c|}{ Reaction time: $12 \mathrm{~h}$} & \multicolumn{4}{|c|}{ Reaction time: 24 h } \\
\hline $\mathrm{T}\left({ }^{\circ} \mathrm{C}\right)$ & $\rho\left(\mathbf{g} / \mathbf{c m}^{3}\right)$ & $\eta(\mathrm{mPa} \cdot \mathrm{s})$ & $v(\mathbf{c S t})$ & $\mathbf{T}\left({ }^{\circ} \mathrm{C}\right)$ & $\rho\left(\mathbf{g} / \mathbf{c m}^{3}\right)$ & $\eta(\mathrm{mPa} \cdot \mathrm{s})$ & $v(\mathbf{c S t})$ \\
\hline 10 & 0.9545 & 7170 & 7512 & 10 & 0.9483 & 4022 & 4241 \\
\hline 25 & 0.9415 & 1554 & 1650 & 25 & 0.9360 & 863.5 & 922.6 \\
\hline 40 & 0.9298 & 400.5 & 430.8 & 40 & 0.9274 & 258.6 & 278.8 \\
\hline 70 & 0.9037 & 115.0 & 127.2 & 70 & 0.9087 & 81.0 & 89.1 \\
\hline 100 & 0.8745 & 43.9 & 50.1 & 100 & 0.8916 & 31.5 & 35.3 \\
\hline 120 & 0.8551 & 25.9 & 30.3 & 120 & 0.8803 & 19.5 & 22.2 \\
\hline
\end{tabular}


between 10 and $120{ }^{\circ} \mathrm{C}$, are listed in Table 4. As can be observed, increments in estolide kinematic viscosities of around $1000 \%$ and $500 \%$ at $40{ }^{\circ} \mathrm{C}$ and $100{ }^{\circ} \mathrm{C}$, respectively, relative to the corresponding olein viscosities, were obtained after a reaction time of $3 \mathrm{~h}$. However, the maximum viscosity values were obtained after reaction times of up to $12 \mathrm{~h}$, matching estolide maximum number-average molecular weight. On the contrary, estolide viscosities significantly decrease after $12 \mathrm{~h}$ reaction time, a fact related to a lower molecular weight. This result confirms that estolide viscosity is controlled by the oligomerization degree (Cermak et al., 2001). The viscosity index for the estolides synthesized in this work was $178 \pm 5$, regardless of reaction time, slightly lower $(7 \%)$ than that obtained for olein.

\section{CONCLUSIONS}

Estolides derived from high-oleic sunflower oil oleins have been obtained. The reaction time for a sulphuric acid-catalyzed conversion of oleins into oligomers significantly affects the averageweight molecular weight and, consequently, the kinematic viscosity of the estolides synthesized. Thus, a dramatic increase in molecular weight was observed after $3 \mathrm{~h}$ of processing, when the largest level of oligomerization takes place. Nevertheless, the maximum viscosities were obtained for reaction times comprising between 6-12 h, coinciding with the maximum values of the average molecular weights. These chemical products could be used as additives to increase the viscosity of vegetable oils for lubricant applications.

\section{ACKNOWLEDGMENTS}

Thanks are due to COREYSA for supplying the olein samples used in this work. This work was supported by research grants from MCYT (PSE320100-2006) and FEDER.

\section{REFERENCES}

Al-Wakeel MI, El-Adly RA (2005). A novel application of Egyptian oil shale as a filler in the production of lithium lubricating grease. Energy Sources 27, 1511-1522.

Becker R, Knorr A (1996). An evaluation of antioxidants for vegetable oils at elevated temperatures. Lubr. Sci. 8, 95-117.

Cermak SC, Isbell TA (2001). Synthesis of Estolides from Oleic and Saturated Fatty Acids. J. Am. Oil Chem. Soc. 78, 557-565.

Cermak SC, Isbell TA (2003). Improved oxidative stability of estolide esters. Ind. Crops Prod. 18, 223-230.

Dumont MJ, Narine SS (2007). Soapstock and deodorizer distillates from North American vegetable oils: Review on their characterization, extraction and utilization. Food Research International 40, 957-974.

El-Adly RA (2000). Producing multigrade lubricating greases from animal and vegetable fat by-products. Synthetic Lubrication 16, 323-332.

García-Zapateiro LA, Franco JM, Valencia C, Gallegos C (2008). Polyestolides as viscosity modifiers of vegetable oils for lubricant applications. In: "Rheology in Product Design and Engineering" (A Guerrero, J Muñoz, JM Franco, eds.), pp 41-44.

Isbell TA, Abbott TP, Asadauskas, S., Lohr JE (2000). Biodegradable oleic estolide ester base stocks and lubricants. Patent no US 6,018,063.

Isbell TA, Kleiman R, Plattner BA (1994). Acid-catalyzed condensation of oleic acid into estolides and polyestolides. J. Am. Oil Chem. Soc. 71, 169-174.

IUPAC (1992) Method 2.301. "Standard methods for the analysis of oils fat and derivatives".- 1st supplement to 7th edition, Pergamon Press, Oxford.

Kodali DR (2002). High Performance Ester Lubricants from Natural Oil. Ind. Lubric. Tribol. 54, 165-170.

Maleque MA, Masjuki HH, Sapuan SM (2003). Based Biodegradable Lubricating Oil Additives. Ind. Lubric. Tribol. 55, 137-143.

Yazicigil Z, Ahmetli G (2008). Synthesis of the Fatty Acid Compounds Obtained from Sunflower Oil Refining Products. J. Appl. Polym. Sci. 108, 541-547. 